
\title{
25 Research Square \\ Effects of Salinity on Gills' Chloride Cells, Stress Indices and Gene Expression of Asian Seabass (Lates Calcarifer, Bloch, 1790)
}

\section{Maryam Azodi}

Persian Gulf University

Mahmoud Nafisi Bahabadi

Persian Gulf University

\section{Ahmad Ghasemi}

Persian Gulf University

Vahid Morshedi ( $\nabla$ v.morshedi@gmail.com )

Persian Gulf University https://orcid.org/0000-0001-7673-2652

\section{Mansour Torfi Mozanzadeh \\ Iranian Fisheries Research Organization}

\section{Raheleh Shahraki}

Shahid Chamran University of Ahvaz

\section{Omid Khademzadeh}

Khorramshahr Marine Science and Technology University

\section{Shirin Hamedi}

Persian Gulf University

\section{Sakineh Avizhgan}

Persian Gulf University

\section{Research Article}

Keywords: Asian seabass, ionocytes, cortisol, heat shock proteins, immune-related genes

Posted Date: June 4th, 2021

DOl: https://doi.org/10.21203/rs.3.rs-534301/v1

License: (c) (i) This work is licensed under a Creative Commons Attribution 4.0 International License. Read Full License 


\section{Abstract}

A two-week research was carried-out to assess water salinity (WS) effects including 0, 15, 35 and $50 \%$ o on osmoregulatory mechanisms and stress indices in Asian sea bass (34.4 g) juveniles. Except for fish reared at 50\%, in the other treatments gradually decreased to the prescribed WS during a 10-day period (-5\% a day). After 10-day of acclimation period, fish reared at the prescribed WS for two weeks. Fish reared at 15 and $35 \%$ had higher chloride cell (CC) counts in the interlamellar region. The number of CC in the interlamellar region elevated with increment of WS up to 35\%, but they were pronouncedly reduced in $50 \%$ group. The diameter of CC in the interlamellar region was not affected by WS. The least nucleus diameter of CC in the interlamellar region was observed in fish reared at $15 \%$ o $(P<0.05)$. The greatest and the least amounts of serum aspartate aminotransferase content were observed in fish reared at freshwater and $15 \%$, respectively. Fish reared at 35\%o had the highest serum sodium and potassium contents. Serum chloride content and total osmolality increased with increment of WS $(P<0.05)$. Serum cortisol and glucose contents gradually increased with elevation of WS up to $35 \%$, then their contents remarkably decreased. The relative expression of insulin like growth factor- 1 in the liver of fish reared at $35 \%$ was strikingly higher than the other groups. The relative expression of $H S P 70$ gene in fresh water group was pronouncedly elevated compared to other treatments. The relative expression of interleukin-1 $\beta$ in 15 and 35\%o groups was higher than the other groups; however, the relative expression of lysozyme gene in the liver of fish reared at fresh water was pronouncedly lower than the other treatments. The results of this study suggested rearing $L$. calcarifer at $15 \%$ o closer to the isosmotic point and better provide its welfare.

\section{Introduction}

Asian seabass (Lates calcarifer) is a protandrous fish and tolerate a wide range of salinities (Mozanzadeh et al., 2021). Because of several favorable characteristics such as high tolerance to sudden environmental changes, great growth and feed utilisation, ease of reproduction in captive condition and high fecundity it has been considered as a worldwide candidate for marine cage culture (Mathew, 2009). Due to its euryhaline characteristics, this species is commercially cultured in different aquaculture systems such as earthen ponds or recirculating systems supplied with fresh or brackish water (0-20\%o) and in marine cages.

Euryhaline fish species have a great capacity to maintain their homoeostasis in hypo- and hypersaline environments (Evans, 2008). Gills, kidneys and gut are the vital organs in euryhaline fish for the uptake and excretion of salt in hypoosmotic and hyperosmotic environments, respectively (Evans et al., 2005). Chlorides cells (CC), mainly developed in gills, particularly developed for osmoregulation (Hirose et al., 2003). These mitochondrial rich cells have high energy requirement for osmoregulation and they contain specific enzymes (e.g. $\mathrm{Na}^{+} / \mathrm{K}^{+}$-ATPase pump among the others) by which they can actively secrete $\mathrm{NaCl}$ (Evans, 2008). It has been confirmed that hyperosmotic environments induce the proliferation of CC (Caberoy \& Quinitio 2000; Carmona et al., 2004), but hypoosmotic condition reduce CC counts in the gills of fish (Fielder et al., 2007). Besides counts, it has been confirmed that size and location of CC in gills and 
also the activity of $\mathrm{Na}^{+} / \mathrm{K}^{+}$-ATPase pump correlate with water salinity (WS) in euryhaline fish (Lin et al., 2003; Laiz-Carrión et al., 2005a; Fielder et al., 2007). It has been confirmed that the function and morphological properties of CC during WS challenges modified by endocrine system are mainly catecholamines and growth hormone (GH) (Sakamoto \& Hirano, 1993; Sakamoto \& McCormick, 2006; Jiang et al., 2008). In this sense, it has been confirmed that increment of plasma cortisol induced CC proliferation and enhanced $\mathrm{Na}^{+}, \mathrm{K}^{-}$-ATPase activity in the gills of Mozambique tilapia (Oreochromis mossambicus, Jiang et al., 2008). Furthermore, GH and insulin-like growth factor I (IGF-1) seem to act synergistically with cortisol in the seawater acclimation process by affecting the activity of $\mathrm{Na}^{+}, \mathrm{K}^{+}-$ ATPase pump in CC (Madsen, 1990; McCormick et al., 1991; Madsen \& Bern, 1993; Sakamoto \& Hirano, 1993; McCormick, 1996; Seale et al., 2002; Sakamoto \& McCormick, 2006). In addition, the amounts of IGF-1 mRNA transcription increased in the liver of coho salmon (Oncorhynchus kisutch) during smolting process (Duan et al., 1995).

Thus, physiological processes also may affect by WS in euryhaline fish such as immunocompetence (ElLeithy et al., 2019) and stress indices (Deane et al., 2004). For example, Gu et al. (2018) reported that acute exposure to hypersaline condition pronouncedly reduced expression of the immune-related genes (e.g. interleukin 1-receptor type 2) in the gill cells of Japanese eels (Anguilla japonica). In addition, upregulation of heat shock protein 70 (HSP70) gene transcript has been observed in Yellow Perch (Perca flavescens) under salinity treatment (Eissa et al., 2017). The above-mentioned authors also demonstrated a strong relationship between IGF-1 and HSP7O genes expression under salt treatment, which suggested them as valuable stress biomarkers in fish.

In this regard, in this study we aimed to assess the influences of different WS on osmoregulatory and physiological responses in L. calcarifer by considering microscopic changes of CC in gills, serum electrolytes, stress indices and transcription of some immune and stress related genes.

\section{Materials And Methods \\ 2.1 Research design}

The current study was run in the aquatic research laboratory of Persian Gulf University, Bushehr, Iran. The juveniles of Asian seabass were purchased from Ramooz company (Delvar, Bushehr) and transferred into the lab. They were stocked into a $1000 \mathrm{~L}$ fiberglass tank. One hundred and eighty L. calcarifer (initial weight $=34.4 \pm 0.4 \mathrm{~g}$ ) juveniles were randomly distributed into twelve 250-L cylindrical polyethylene tanks (15 specimens in each tank) that supplied with hypersaline (50\%) that pumped from Persian Gulf. The selected WS treatments were fresh water (0\%o), 15, 35 and 50\%. Except for the 50\%o group, WS in the other treatments gradually decreased to the prescribed WS during a 10-day period (-5\%o per a day). After 10-day of acclimation period, fish were reared at the prescribed WS for two weeks. The husbandry system was supplied with sand-filtered and disinfected water with the prescribed salinities. The prescribed WS were adjusted by diluting hypersaline water $(50 \%$ ) of Persian Gulf with fresh water in 1000-L polyethylene tanks and pumped into the system. The mean values (mean \pm standard deviation) for 
temperature, $\mathrm{pH}$ and dissolved oxygen were $25.0 \pm 2.0^{\circ} \mathrm{C}, 7.9 \pm 0.2$ and $80 \%$ saturation level, respectively and photoperiod was 12L: 12D (Light: Darkness). About 70\% of water of system was exchanged with new water daily. Fish were fed twice daily (0800 and 1600) with a commercial diet (size $3.0 \mathrm{~mm}, 500 \mathrm{~g}$ $\mathrm{kg}^{-1}$ protein, $160 \mathrm{~g} \mathrm{~kg}^{-1}$ lipid, Beyza Feed Mill 21, Shiraz, Iran) to visual satiation for two weeks.

\subsection{Sampling}

After finishing two-weeks of the husbandry trial, six specimens of each tank were anesthetized with 2phenoxyethanol and blood samples was collected from their caudal vein with syringes. Five $h$ after blood coagulation, blood samples were centrifuged (4000 g, $10 \mathrm{~min}$, at room temperature) and serum was separated and was kept at $-80^{\circ} \mathrm{C}$ until their analysis. After blood collection, the same fish were sacrificed with an overdose $\left(1000 \mathrm{mg} \mathrm{L}^{-1}\right)$ of the anesthetic to dissect gills and the liver. The dissected gill was fixed in formalin $10 \%$ for $24 \mathrm{~h}$ and then transferred to $70 \%$ ethanol until examination and the liver samples were snap-frozen by using liquid nitrogen then kept in $-80^{\circ} \mathrm{C}$ until their analysis.

\subsection{Histological studies and serum biochemical assessments}

A classic histology along with hematoxylin and eosin staining methods were done for evaluating the histoarchitecture of $\mathrm{CC}$ in the gills samples using an Olympus $\mathrm{BH}-2$ photomicroscope. A computerized microscopic image analyzer (Digimizer 4.1.1) was used to determine histomorphometric parameters of gills including number of chloride cells (CC) in the interlamellar region, diameter of CC and their nucleus in the interlamellar region of 10 fish per treatment were evaluated.

Serum glucose (GLU), alkaline phosphatase (ALP), alanine aminotransferase (ALT), aspartate aminotransferase (AST) and electrolytes (sodium, potassium and chloride) were measured by means of an automated analyzer (Technicon RA-1000, Technicon Instruments) using diagnostic kits (Pars Azmoon Kit, Iran). Serum cortisol concentration was measured by radioimmunoassay using a commercial kit (\#IM1841, Beckman Coulter, Immunotech) (Ellis et al., 2004). Serum total osmolality (mOsmol kg-1) were determined by a freezing point osmometer (Knauer, $\mathrm{K}-7400$, Germany). Plasma $\mathrm{Cl}^{-}, \mathrm{Na}^{+}$and $\mathrm{K}^{+}$levels were measured was determined by atomic absorption spectrophotometry (Radiometer mod. EML-100).

\subsection{Evaluation of relative expression of growth and immune-related genes in the liver}

Total RNA of the liver samples was extracted by a commercial kit (Roche, Manheim, Germany) as described by the manufacturer instructions and then were treated with DNase I to remove contaminating genomic DNA. RNA quantity and purity were assessed by measuring the A260/A280 ratio using Spectrophotometer (Biotech photometer WPA), and the RNA quality was assessed through electrophoresis on a $1 \%$ agarose gel. Elongation factor 1 a was applied for internal housekeeping gene as used a suitable reference gene by Mohd-Shaharuddin et al. (2015) and Paria et al. (2015) in previous studies on Asian seabass. A cDNA synthesis Kit (Cinna gene, Tehran, Iran) and primers (oligo(dT), 
Random Hexamer (Metabion)) following the manufacturer's instructions was applied for synthesizing cDNA. The expression of insulin-like growth factor I (IGF-1), interleukin $1 \beta(I L-1 \beta)$, heat shock protein 70 (HSP70) and lysozyme in the liver of $L$. calcarifer juveniles were assessed by quantitative real-time PCR assays in triplicate (Table 1). A real-time PCR machine (Rotor Gene-3000, Sydney, Australia) was applied to assess the expressions of these genes as described by Zeynali et al. (2020). The Ct of Ef1a under the influence of salinity did not change significantly between different treatments $(P<0.01)$. Data analysis of the real-time PCR was performed in triplicate with Rotor-Gene, RG-3000 (Australia) software. The relative expression levels of candidate genes were calculated using the 2- $\Delta \Delta \mathrm{Ct}$ method (Livak \& Schmittgen, 2001).

Table 1

Primers sequences and amplification efficiencies

\begin{tabular}{|lllll|}
\hline Gene name & Sequences of primers & Accession number & Efficiency & Product size \\
\hline Ef1a & F: AAATTGGCGGTATTGGAAC & GQ507427.1 & $97 \%$ & 83 \\
& R: GGGAGCAAAGGTGACGAC & & & \\
\hline IGF-1 & F: ACGCTGCAGTTTGTATGTGG & XM_018697285.1 & $98 \%$ & 157 \\
& R: CCTTAGTCTTGGGAGGTGCA & & & \\
\hline HSP70 & F: AAGGCAGAGGATGATGTC & HQ646108.1 & $97 \%$ & 186 \\
& R: TGCAGTCTGGTTCTTGTC & & \\
\hline IL-1 $\beta$ & F: CCTGTCGCATTTCAGTACGG & XM_018669006.1 & $95 \%$ & 147 \\
& R: ATTTCCACCGGCTTGTTGTC & & & \\
\hline Lysozyme & F: GGTGTTTCTGCTCTTGGTGG & XM_018667849.1 & $99 \%$ & 196 \\
& R: GCCGTAGTCAGTGGATCCAT & & & \\
\hline
\end{tabular}

\subsection{Statistical assessments}

A SPSS ver. 16.0 (Chicago, IL, USA) software was used for data analyses. Kolmogorov-Smirnov and Leven tests were used for confirmation of normality and homogeneity of data, respectively. A one-way ANOVA and Duncan's multiple-range as post-hoc test were performed for comparisons between groups. The $P<0.05$ was considered as significant for all statistical tests.

\section{Results}

The survival rate in all groups was $100 \%$. The histological study of the gill demonstrated that fish reared at 15 and $35 \%$ had more CC counts in the interlamellar region $(P<0.05$, Table 2 , Fig. 1,2$)$. The number 
of CC in the interlamellar region increased with increasing WS up to 35\%o, but they decreased in fish reared at $50 \%$ o. The diameter of CC in the interlamellar region was not affected by WS. The nucleus diameter of CC in the interlamellar region in fish reared at 15\%o was lower than the other groups $(P<$ 0.05).

\section{Table 2}

Gills' chloride cells (CC) morphology of Lates calcariferjuveniles reared in water salinities $(0,15,35$ and $50 \%$ ) at the end of the trial. A different superscript in the same row denotes statistically significant differences $(P<0.05)$.

\begin{tabular}{|c|c|c|c|c|}
\hline \multirow[b]{2}{*}{ Treatments } & \multicolumn{4}{|c|}{ Water salinities $(\%$ o) } \\
\hline & 0 & 15 & 35 & 50 \\
\hline $\mathrm{CC}$ counts in the interlamellar region & $6.4 \pm 0.5^{b}$ & $9.6 \pm 0.5^{a}$ & $9.0 \pm 0.6^{a}$ & $7.5 \pm 0.4^{b}$ \\
\hline Diameter of $\mathrm{CC}$ in the interlamellar region & $7.9 \pm 0.2^{\mathrm{a}}$ & $7.1 \pm 0.3^{\mathrm{a}}$ & $7.0 \pm 0.3^{a}$ & $7.6 \pm 0.2^{\mathrm{a}}$ \\
\hline $\begin{array}{l}\text { Diameter of CC nucleus in the interlamellar } \\
\text { region }\end{array}$ & $5.3 \pm 0.1^{\mathrm{a}}$ & $4.8 \pm 0.2^{b}$ & $5.4 \pm 0.3^{\mathrm{a}}$ & $5.7 \pm 0.2^{\mathrm{a}}$ \\
\hline
\end{tabular}

Serum ALP and ALT contents did not change in fish reared at different WS (Table 3). Fish reared at freshwater and $15 \%$ o had the highest while lowest serum AST content, respectively $(P<0.05)$.

Table 3

Serum enzymes contents $\left(\mathrm{UL}^{-1}\right)$ (mean $\pm \mathrm{SE}, \mathrm{n}=3$ tank) of Lates calcarifer juveniles reared in water salinities $(0,15,35$ and $50 \%$ o) at the end of the trial. A different superscript in the same row denotes statistically significant differences $(P<0.05)$.

\begin{tabular}{|lllll|}
\hline \multicolumn{5}{|c|}{ Water salinities (\%o) } \\
\hline Treatments & 0 & 15 & 35 & 50 \\
\hline CC counts in the interlamellar region & $6.4 \pm 0.5^{\mathrm{b}}$ & $9.6 \pm 0.5^{\mathrm{a}}$ & $9.0 \pm 0.6^{\mathrm{a}}$ & $7.5 \pm 0.4^{\mathrm{b}}$ \\
\hline Diameter of CC in the interlamellar region & $7.9 \pm 0.2^{\mathrm{a}}$ & $7.1 \pm 0.3^{\mathrm{a}}$ & $7.0 \pm 0.3^{\mathrm{a}}$ & $7.6 \pm 0.2^{\mathrm{a}}$ \\
\hline Diameter of CC nucleus in the interlamellar region & $5.3 \pm 0.1^{\mathrm{a}}$ & $4.8 \pm 0.2^{\mathrm{b}}$ & $5.4 \pm 0.3^{\mathrm{a}}$ & $5.7 \pm 0.2^{\mathrm{a}}$ \\
\hline $\begin{array}{l}\text { Abbreviations: ALP: alkaline phosphatase; ALT: alanine aminotransferase; AST: aspartate } \\
\text { aminotransferase. }\end{array}$ & \\
\hline
\end{tabular}


Fish reared at $35 \%$ o had the highest serum sodium and potassium contents and fish reared at 15 and $50 \%$ o showed the lowest values (Table 4). Serum chloride content and total osmolality increased with increment of WS $(P<0.05)$.

\section{Table 4}

Serum electrolytes $\left(\mathrm{mmol} \mathrm{L}^{-1}\right)$ and total osmolality $\left(\mathrm{mOsmol} \mathrm{kg}{ }^{-1}\right)$ (mean $\pm \mathrm{SE}, \mathrm{n}=3$ tank) of Lates calcarifer juveniles reared in water salinities $(0,15,35$ and $50 \%)$ at the end of the trial. A different superscript in the same row denotes statistically significant differences $(P<0.05)$.

\begin{tabular}{|lllll|}
\hline \multicolumn{5}{|l|}{ Water salinities (\%o) } \\
\hline Treatments & 0 & 15 & 35 & 50 \\
\hline Sodium & $114.0 \pm 1.0^{\mathrm{b}}$ & $102.7 \pm 3.8^{\mathrm{c}}$ & $157.7 \pm 2.1^{\mathrm{a}}$ & $95.0 \pm 2.1^{\mathrm{c}}$ \\
\hline Potassium & $3.2 \pm 0.2^{\mathrm{b}}$ & $2.4 \pm 0.2^{\mathrm{c}}$ & $3.9 \pm 0.1^{\mathrm{a}}$ & $2.3 \pm 0.1^{\mathrm{c}}$ \\
\hline Chloride & $135.3 \pm 1.8^{\mathrm{b}}$ & $146.3 \pm 7.8^{\mathrm{b}}$ & $161.7 \pm 1.5^{\mathrm{a}}$ & $170.0 \pm 1.0^{\mathrm{a}}$ \\
\hline Total Osmolality & $391.7 \pm 2.9^{\mathrm{c}}$ & $413.7 \pm 1.8^{\mathrm{b}}$ & $438.7 \pm 5.2^{\mathrm{a}}$ & $439.3 \pm 2.7^{\mathrm{a}}$ \\
\hline
\end{tabular}

Serum cortisol (Fig. 3a) and glucose (Fig. 3b) levels gradually increased with elevation of WS up to 35\%o, then their contents remarkably decreased in serum of fish reared at $50 \%$.

The relative expression of IGF-1 in the liver of fish reared at 35\%o was significantly higher than the other groups, but fish reared at fresh water and 15\%o showed the lowest liver IGF-1 gene expression (Fig. 4a). The relative expression of $I L-1 \beta$ in the liver of fish reared at 15 and $35 \%$ o was higher than at fresh water and $50 \%$ o (Fig. $4 \mathrm{~b}$ ). The relative expression of $H S P 70$ gene in fish reared at fresh water was pronouncedly higher than other treatments (Fig. 4c); however, the relative expression of lysozyme gene in the liver of fish reared at fresh water was remarkably lower than those reared at salt waters (Fig. 4d).

\section{Discussion}

In many teleosts, changes in counts and/or dimension of CC mainly correlated to acclimation to WS throughout ontogenic development (Hiroi \& McCormick, 2007). The findings of the present research indicated that the CC morphology in the gills remarkably responded to different WS. The number of CC in the interlamellar region pronouncedly increased in fish with increment of WS especially in fish reared at $35 \%$, then decreased at $50 \%$ o. It was noticed that, the proliferation of CC particularly in fish reared at $35 \%$ o was coincided with elevation of serum cortisol level and up-regulation of the liver IGF-1 gene. These results suggesting the direct influence of these hormones on osmoregulation of $L$. calcarifer by modifying the morphology of CC in the gills. Furthermore, the augmentation of CC counts indicating the greater 
requirement for ionoregulation through these cells for keeping homeostasis. Similarly, remarkable increment of CC counts in the gill filaments was reported in different hyperosmotic-acclimated fish such as European sea bass (Dicentrarchus labrax, Varsamos et al., 2002), killifish (Lima \& Kültz, 2004), Adriatic sturgeon (Acipenser naccarii, Martínez-Álvares et al., 2005), Mozambique tilapia (Hiroi et al., 2005), fat snook (Centropomus parallelus, Sterzelecki et al., 2013). It should be mentioned that fish reared at $15 \%$ had the smallest nucleus diameter in CC suggesting these fish were at isosmotic condition and less osmotic stress pressure was on them; however, fish reared at other WS showed nucleus hypertrophy mas a result of hypo and/or hyperosmotic stress condition. Similarly, Laiz-Carrión et al., (2005a) revealed that the number and size of CC were remarkably enhanced in gilthead seabream reared at $5 \%$ ond $60 \%$, whereas exposure of fish to intermediate WS (15\%o and 25\%o) reduced their CC size as a result of lower need for ion pumps required in fish reared at isosmotic environments. Increment of CC size in the hypoand/or hyperosmotic environments indicates the increasing the permeability of cells' junctions and CC complexes for augmentation of $\mathrm{Na}^{+}$and $\mathrm{Cl}^{-}$turnover (Miyazaki et al., 1998).

The amount of liver enzymes in body's fluids is valuable biomarkers of fish welfare and health in response to stressful condition (Wagner \& Congleton, 2004). In the present study, the amount of serum ALP and ALT did not change in fish reared at different WS, but fish reared at fresh water or $15 \%$ o had the highest and least amount of plasma AST. These results indicated that fish reared at freshwater may be metabolized amino acids derived from proteolysis or used exogenous amino acids pool as a fuel source for gluconeogenic activity to cope with stressful condition; meanwhile fish reared at isosmotic condition (15\%) underwent the least stress. In accordance with these findings, Farshadian et al., (2018) revealed that the value of ALP was not affected in yellowfine seabream reared at $5 \%$ ond $35 \%$.

In this study, serum cortisol increased in fish reared at 35\%o that was in concomitant with hyperglycemia and the up-regulation of the liver IGF-1 gene that may be correlated with increase of CC in the interlamellar region. It should be mentioned that the concentrations of serum $\mathrm{Na}^{+}$and $\mathrm{K}^{+}$also increased in fish reared at $35 \%$ o that may as consequence of increase in CC counts in this group. These findings indicated that cortisol and IGF-1 can synergically enhance the salinity resistance in L. calcarifer. In this sense, it has been reported that cortisol can act directly on gills to augment $\mathrm{Na}^{+}, \mathrm{K}^{+}$-ATPase activity and CC density (Madsen \& Bern, 1993). The increment of serum glucose in fish reared at $35 \%$ may be related to the increasing transfer of metabolites as a stored fuel source to deal with stress and to satisfy the energy demand for higher $\mathrm{Na}^{+}, \mathrm{K}^{+}$-ATPase activity in $\mathrm{CC}$ under the regulation of adrenalin and cortisol hormones (Wendelaar-Bonga, 2011).

The determination of the amounts of blood electrolytes, especially $\mathrm{Na}^{+}, \mathrm{K}^{+}$and $\mathrm{Cl}^{-}$, and osmolality and ion levels after changes in WS can provide information regarding the ionoregulatory ability and also successful acclimation of fish in a saline environment (Stewart et al., 2016). In the current research, the amounts of serum $\mathrm{Na}^{+}$and $\mathrm{K}^{+}$pronouncedly enhanced in fish reared at $35 \%$ o that was associated with enhancing serum cortisol in this group indicating the increment tightening the junction between polygonal pavement cells in order to limit passive salt gain or loss during SW or FW acclimation, 
respectively (Chasiotis et al., 2012). However, the levels of these ions in fish reared at $35 \%$ o were higher than those reared at 15 and $50 \%$ o. In this context, because of any correlation among result of Na with other ions and osmolality, the significant difference in the metioned parameter could probably be attributed to an error in $\mathrm{Na}^{+}$evaluation in the lab. In our study, the serum osmolality and $\mathrm{Cl}^{-}$linearly enhanced with elevation of WS suggesting strong osmoregulatory ability of this species as also reported in other euryhaline fish (Laiz-Carrion et al., 2005b; Saud et al., 2007; Herrera et al., 2009; Vargas-Chacoff et al., 2011). It has been suggested that these increased ions levels are due to elevated $\mathrm{Na}^{+} / \mathrm{K}^{+}$-ATPase activities mainly in gut and kidney for uptaking ions from gut fluids and urine.

In euryhaline teleosts, GH and IGF-1 have osmoregulatory effects and act on the gill is through changes in tissue responsiveness to cortisol through elevation the numbers of gill cortisol receptors (Shrimpton et al., 1995; Sakamoto \& McCormick, 2006). Thus, GH and IGF-1 synergically along with cortisol appears to control gills' osmoregulatory function by affecting the activity of $\mathrm{Na}^{+} / \mathrm{K}^{+}$-ATPase, distribution and density of CC (Sakamoto \& McCormick, 2006; Deane \& Woo, 2009). In the current research, the expression of IGF1 remarkably enhanced in the liver of fish reared at 35 and $50 \%$ indicating the key role of this hormone for maintaining homeostasis at hyperosmotic environments. In addition, up-regulation of liver IGF-1 gene in 35\%o group was associated with the increment of serum cortisol, which consequently enhanced CC in the interlamellar region in this group. Similarly, it has been found that liver IGF-1 expression increased by seawater exposure in black sea bream and Atlantic salmon (Deane \& Woo 2005; Breves et al., 2017).

The HSP family mainly functions as molecular chaperones in cells to prohibit protein disruption, regulate protein homeostasis and contribute in refolding of misfolded proteins. They are also implicated in the general protection of stressed cells (Basu et al., 2002). Our findings demonstrated that fish reared at freshwater has higher liver HSP70 gene expression that was coincided with the highest liver AST content compared to other groups suggesting this treatment was under stressful condition. These results indicate a direct role of the stress protein in salinity tolerance by L. calcarifer. The key role of HSP7O in the adaptation of fish to changes of WS has been well documented (Smith et al., 1999). For example, hypoor hyperosmotic shock enhanced the branchial expression of HSP70 in the silver sea bream (Sparus sarba, Deane et al., 2004). The authors of the above-mentioned study revealed that the activity and mRNA levels of HSP70 were lower around isosmotic WS that was attributed to the best growth performance in silver sea bream.

It has been confirmed that there is a direct relationship between immune-related genes and environmental salinity in fish (Gu et al., 2018). Inflammatory-related genes (pro-inflammatory cytokines) such as IL-1 $\beta$ enable the organisms in responding to stress condition by inducing neutrophil chemo-attractant ability and their migration toward inflammatory sites (Uribe et al., 2011). In the present study, rearing fish at 15 and $35 \%$ induced liver $I L-1 \beta$ up-regulation suggesting changes in WS can modify immune responses in this species. Similar to our findings, proliferation of leucocytes and their activities after acute salinity change were found in pipefish (Syngnathus typhle) (Birrer et al., 2012). Furthermore, El-Leithy et al. (2019) reported that levels of IL-1 $\beta$, IL-8, and cc-chemokine were higher in the liver of Nile tilapia (Oreochromis niloticus) reared at $16 \%$ o compared to groups reared at $20 \%$ o suggesting pro-inflammatory respond in 
fish reared at $16 \%$ o. In contrast, Choi et al. (2012) reported that rapid decreases in salinity, did not affect splenic leucocytes IL-1 $\beta$ transcription in Nile tilapia. In addition, chronic hyperosmotic stress in striped catfish (Pangasianodon hypophthalmus, Sauvage), inhibited kidneys' toll-like receptors expression suggesting immune-suppressive effects of salinity stress (Schmitz et al. 2017).

Lysozyme possesses a direct antibacterial effect by splitting peptidoglycan layers of Gram-positive bacteria and act as an opsonin that trigger phagocytes to destroy Gram-negative bacteria (Yano, 1996). In the present study, Lysozyme gene expression down-regulated in the liver of fish reared at freshwater that was associated with up-regulation of the liver HSP7O in this group suggesting immunosuppressive effects of hypoosmotic stress. In this sense, Yada et al. (2012) reported that hyperosmotic condition increased LZ gene expression in the gills of Atlantic salmon (Salmo salar). Furthermore, it has been reported that increasing WS enhanced serum/plasma lysozyme activity in brown trout (Marc et al., 1995), rainbow trout (Yada et al., 2001; Fast et al., 2002), Nile tilapia (Dominguez et al., 2005), sablefish (Kim et al., 2017), yellowfin seabream and Asian seabass (Mozanzadeh et al., 2021). These results indicate that WS can directly affect fish immunocompetence by affecting immune-related genes, chaperones as well as endocrine system especially catecholamines and $\mathrm{GH}$.

In conclusion, the findings of this study indicated that changes in WS pronouncedly alter the histoarchitecture of CC of gills maybe through stress response pathway (e.g. cortisol) and IGF-1 also synergically modified these responses. Immune-related genes also triggered by intermediate WS (15 and $35 \%$ ), suggesting mediatory role of WS in fish immunity. Finally, rearing L. calcarifer at intermediate salinities (e.g. 15\%o) is suggested because of lower concentration of AST in the liver and this salinity is closer to its isotonic point compared to the other salinities.

\section{Declarations}

\section{Funding}

This research has been financially supported by Persian Gulf University, Bushehr, Iran. The authors would like to thank the staff at Mariculture Research Station of the Persian Gulf Research Institute (PGRI) for providing juvenile fish and the rearing facilities for this experiment.

\section{Authors' contributions}

All persons listed as authors have read, contributed to preparing the manuscript as given below:

Maryam Azodi, Sakineh Avizhgan and Ahmad Ghasemi carried out fish maintenance and sample collection

Mahmoud Nafisi Bahabadi carried out experimental design and statistical analyses Vahid Morshedi carried out digestive enzymes analyses 
Raheleh Shahraki, Omid Khademzadeh and Shirin Hamedi carried out antioxidant enzymes analyses

Mansour Torfi Mozanzadeh carried out data interpretation

\section{Ethics approval}

This study was carried out in accordance with the principle of the Basel Declaration and recommendations of the Faculty of Veterinary Medicine at University of Tabriz, the FVM.REC.1396.939. The protocol was approved by the FVM.REC.1396.939.

\section{Conflicts of interest/Competing interests}

The authors declare that they have no conflict of interest.

\section{Availability of data and material (data transparency)}

The data that support the findings of this study are available from the corresponding author upon reasonable request.

\section{Consent to participate}

The authors declare that they have every consent to participate.

\section{Consent for publication}

The authors declare that they have every consent for publication.

\section{References}

1. Basu, N., Todgham, A. E., Ackerman, P. A., Bibeau, M. R., Nakano, K., Schulte, P. M., Iwama, G. K. (2002). Heat shock protein genes and their functional significance in fish. Gene, 295, 173-183.

2. Breves, J. P., Fujimoto, C. K., Phipps-Costin, S. K., Einarsdottir, I. E., Björnsson, B. T., McCormick, S. D. (2017). Variation in branchial expression among insulin-like growth-factor binding proteins (igfbps) during Atlantic salmon smoltification and seawater exposure. BMC Physiology 17(1):2.

3. Birrer, S.C. Reusch, T.B.H. \& Roth, O. (2012). Salinity change impairs pipefish immune defence, Fish and Shellfish Immunology, 33, 1238-1248.

4. Caberoy, N. B. \& Quinitio, G.F. (2000). Changes in $\mathrm{Na}^{+}, \mathrm{K}^{+}$-ATPase activity and gill chloride cell morphology in the grouper Epinephelus coioides larvae and juveniles in response to salinity and temperature. Fish Physiology and Biochemistry, 23, 83-94.

5. Carmona, R., García-Gallego, M., Sanz, A., Domezaín, A., Ostos-Garrido, M.V. (2004). Chloride cells and pavement cells in gill epithelia of Acipenser naccarii: ultrastructural modifications in seawateracclimated specimens. Journal of Fish Biology, 64, 553-566. 
6. Chasiotis, H., Kolosov, D., Bui, P., \& Kelly, S.P., 2012. Tight junctions, tight junction proteins and paracellular permeability across the gill epithelium of fishes: A review. Respiratory Physiology \& Neurobiology 184, 269- 281.

7. Choi, K., Cope, W.G., Harms, C.A., Law, \& J.M. (2012). Rapid decreases in salinity, but not increases, lead to immune dysregulation in Nile tilapia, Oreochromis niloticus (L.). Journal of Fish Diseases, 36, 389-399.

8. Cuesta, A., Laiz-Carrion, R., Del Rı, M. P., Meseguer, J., Mancera, J. M., \& Esteban, M. A. (2005). Salinity influences the humoral immune parameters of gilthead seabream (Sparus aurata L.). Fish Shellfish Immunology, 18, 255-61.

9. Deane, E. E., Kelly, S. P., Luk, J. C. Y., \& Woo, N. Y. S. (2002). Chronic salinity adaptation modulates hepatic heat shock protein and insulin-like growth factor I expression in black sea bream. Marine Biotechnology, 4, 193-205.

10. Deane, E. E., \& Woo, N.Y.S. (2004). Differential gene expression associated with euryhalinity in sea bream (Sparus sarba). American Journal of Physiology Regulatory, Integrative and Comparative Physiology, 287, 1054-1063.

11. Deane, E. E., \& Woo, N. Y. S. (2005). Upregulation of the somatotropic axis is correlated with increased G6PDH expression in black sea bream adapted to iso-osmotic salinity. Annals of theNew York Academy of Sciences, 1040, 293-296.

12. Deane, E. E., \& Woo, N. Y. (2009). Modulation of fish growth hormone levels by salinity, temperature, pollutants and aquaculture related stress: a review. Reviews in Fish Biology and Fisheries, 19, 97120.

13. Duan, C. M., Plisetskaya, E. M., \& Dickhoff, W. W. (1995). Expression of insulin-like growth factor I in normally and abnormallydeveloping coho salmon (Oncorhynchus kisutch). Endocrinology, 136, 446452.

14. Eissa, N., Wang, H-P., Yao, H., Shen, Z-G., Shaheen, A. A., \& Abou-ElGheit, E. N. (2017). Expression of Hsp70, Igf1, and three oxidative xtress biomarkers in response to handling and salt treatment at different water temperatures in yellow Perch, Perca flavescens. Frontiers in Physiology 8, 683. doi: 10.3389/fphys.2017.00683.

15. El-Leithy, A. A. A., Hemeda, S. A., Abd El Naby, W. S. H., El Nahas, A. F., Hassan, S. A. H., Awad, S. T., ElDeeb, S. I., \& Helmy, Z. A. (2019). Optimum salinity for Nile tilapia (Oreochromis niloticus) growth and mRNA transcripts of ion-regulation, inflammatory, stress- and immune-related genes. Fish Physiology and Biochemistry, 45, 1217-1232.

16. Ellis, T., James, J.D., Stewart, C. \& Scott, A.P. (2004). A non-invasive stress assay based upon measurement of free cortisol released into the water by rainbow trout (Oncorhynchus mykiss). Journal of Fish Biology, 65, 1233-1252.

17. Evans, D. H., Piermarini, P. M., \& Choe, K. P. (2005). The multifunctional fish gill: dominant site of gas exchange, osmoregulation, acid-base regulation, and excretion of nitrogenous waste - Physiological Reviews, 85, 97-177. 
18. Evans, D. H. (2008). Osmotic and Ionic Regulation: Cells and Animals. Boca Raton, FL: CRC Press.

19. Farshadian, R., Salati, A. P., Keyvanshokooh, S., \& Pasha-Zanoosi, H. (2018). Physiological responses of Yellowfin seabream (Acanthopagrus latus) to acute salinity challenge. Marine and Freshwater Behaviour and Physiology, 51(5), 313-325.

20. Fast, M. D., Sims, D. E., Burka, J. F., Mustafa, A., \& Ross, N. W. (2002). Skin morphology and humoral non-speciçc defense parameters of mucus and plasma in rainbow trout, coho and Atlantic salmon. Comparative Biochemistry and Physiology Part A.132, 645-657.

21. Fazio, F., Marafioti, S., Arfuso, F., Piccione, G., \& Faggio, C. (2013). Influence of different salinity on haematological and biochemical parameters of the widely cultured mullet, Mugil cephalus. Marine and Freshwater Behaviour and Physiology, 46, 211-218.

22. Fielder D.S., Allan G.L., Pepperall D., \& Pankhurst P.M. (2007). The effects of changes in salinity on osmoregulation and chloride cell morphology of juvenile Australian snapper, Pagrus auratus. Aquaculture, 272, 656-666.

23. Gu, J., Dai, S., Liu, H., Cao, Q., Yin, S., Lai, K. P., Tse, W. K. F., Wong, C. K. C., \& Shi, H. (2018). Identification of immune-related genes in gill cells of Japanese eels (Anguilla japonica) in adaptation to water salinity changes. Fish and Shellfish Immunology, 73, 288-296.

24. Herrera, M., Vargas-Chacoff, L., Hachero, I., Ruı z-Jarabo, I., Rodiles, A., Navas, J. I., \& Mancera, J. M. (2009). Osmoregulatory changes in wedge sole (Dicologoglossa cuneata Moreau, 1881) after acclimation to different environmental salinities. Aquaculture Research, 40, 762-771.

25. Hiroi, J., McCormick, S.D., Ohtani-Kaneko, R., \& Kaneko, T. (2005). Functional classification of mitochondrion-rich cells in euryhaline Mozambique tilapia (Oreochromis mossambicus) embryos, by means of triple immunofluorescence staining for $\mathrm{Na}^{+} / \mathrm{K}^{+}$-ATPase, $\mathrm{Na}^{+} / \mathrm{K}^{+} / 2 \mathrm{Cl}^{-}$cotransporter and CFTR anion channel. Journal of Experimental Biology, 208, 2023-2036.

26. Hiroi, J., \& McCormick, S.D. (2007). Variation in salinity tolerance, gill Na+/K+-ATPase, $\mathrm{Na}+/ \mathrm{K}+/ 2 \mathrm{Cl}-$ cotransporter and mitochondria rich cell distribution in three salmonids Salvelinus namycush, Salvelinus fontinalis, and Salmo salar. The Journal of Experimental Biology, 210, 1015-1024.

27. Hirose, S., Kaneko, T., Naito, N., \& Takei, Y. (2003). Molecular biology of major components of chloride cells. Comparative Biochemistry and, Physiology part B, 136, 593-620.

28. Jiang, I. F., Kumar, V. B., Lee, D. N., \& Weng, C. F. (2008). Acute osmotic stress affects Tilapia (Oreochromis mossambicus) innate immune responses. Fish and Shellfish Immunology, 25, 841-846.

29. Kim, J.H., Park, H.J., Kim, K.W., Hwang, I.K., Kim, D.H., Oh, C.W., \& Kang, J.C. (2017). Growth performance, oxidative stress, and non-specific immune responses in juvenile sablefish, Anoplopoma fimbria, by changes of water temperature and salinity. Fish Physiology and Biochemistry 43, 14211431.

30. Laiz-Carrión, R., Guerrero, P. M., Fuentes, J., Canario, A. V. M., Martín de Río, M. P., \& Mancera, J.M. (2005a). Branchial osmoregulatory response to salinity in the gilthead sea bream, Sparus auratus. Journal of Experimental Zoology Part A, 303, 563-576. 
31. Laiz-Carrión, R., Sangiao-Alvarellos, S., Guzmán, J.M., Martín del Río, M.P., Soengas, J.L., \& Mancera, J.M. (2005b). Growth performance of gilthead sea bream Sparus aurata in different osmotic conditions: implications for osmoregulation and energy metabolism. Aquaculture, 250, 849-861.

32. Lima, R. N., \& Kultz, D. (2004). Laser scanning cytometry and tissue microarray analysis of salinity effects on killifish chloride cells. Journal of Experimental Biology, 207, 1729-1739.

33. Lin, Y. M., Chen, C. N., \& Lee, T. H. (2003). The expression of gill Na, K-ATPase in milkfish Chanos chanos, acclimated to seawater, brackish water and fresh water. Comparative Biochemistry and Physiology Part A, 135, 489-497.

34. Livak, K. J., \& Schmittgen, T. D. (2001). Analysis of relative gene expression data using real-time quantitative PCR and the 2- $\Delta \Delta \mathrm{C}(\mathrm{T})$ method. Methods, 25, 402-408.

35. Madsen, S.S. (1990). The role of cortisol and growth hormone in seawater adaptation and development of hypoosmoregulatory mechanisms in sea trout parr (Salmo trutta trutta). General and Comparative Endocrinology, 79, 1-11.

36. Madsen, S. S., \& Bern, H. A. (1993). In vitro effects of insulin-like growth factor-I on gill $\mathrm{Na+}, \mathrm{K}+-$ ATPase in coho salmon, Oncorhynchus kisutch. Journal of Endocrinology, 138, 23-30.

37. Marc, A., Quentel, C., Severe, A., Le Bail, P., \& Boeuf, G. (1995). Changes in some endocrinological and non-specific immunological parameters during seawater exposure in the brown trout. Journal of Fish Biology, 46, 1065-1081.

38. Martinez-Álvarez, R. M., Sanz, A., Garcia-Gallego, M., Domezain, A., Domezain, J., Carmona, R. V., Ostos-Garrido, M. \& Morales, A. E. (2005). Adaptive branchial mechanisms in the sturgeon Acipenser naccarii during acclimation to saltwater. Comparative Biochemistry and Physiology-Part A: Molecular and Integrative Physiology, 141, 183-190.

39. Mathew G. (2009). Taxonomy, identification and biology of Seabass (Lates calcarifer). In: Imelda J., Edwin J. V., \& Susmitha V., (Eds). Course manual: national training on cage culture of seabass. Kochi: CMFRI \& NFDB; p. 38-43.

40. McCormick S. D. (1990). Cortisol directly stimulates differentiation of chloride cells in tilapia opercular membrane. American Journal of Physiology, 259, 857-863.

41. McCormick, S. D., Sakamoto, T., Hasegawa, S., \& Hirano, T. (1991). Osmoregulatory action of insulinlike growth factor I in rainbow trout (Oncorhynchus mykiss). Journal of Endocrinology, 130, 87-92.

42. McCormick, S.D. (1996). Effects of growth hormone and insulin-like growth factor I on salinity tolerance and gill Na+/K+-ATPase in Atlantic salmon (Salmo salar): interaction with cortisol. General and Comparative Endocrinology, 101,3-11.

43. Miyazaki, H., Kaneko, S., Hasegawa, S., \& Hirano, T. (1998). Developmental changes in drinking rate and ion and water permeability during early life stages of euryhaline tilapia, Oreochromis mossambicus, reared in fresh water and seawater. Fish Physiology and Biochemistry, 18, $277-284$.

44. Mohammed-Geba, K., González, A. A., Suárez, R. A., Galal-Khallaf, A., Martos-Sitcha, J. A., Ibrahim, H. M., \& Mancera, J. M. (2017). Molecular performance of Prl and Gh/lgf1 axis in the Mediterranean 
meager, Argyrosomus regius, acclimated to different rearing salinities. Fish Physiology and Biochemistry, 43, 203-216.

45. Mohd-Shaharuddin, N., Mohd-Adnan, A., Kua, B.C. \& Nathan, S. (2013). Expression profile of immunerelated genes in Lates calcarifer infected by Cryptocaryon irritans. Fish \& shellfish immunology, 34(3), 762-769.

46. Morgan, J. D., Sakamoto, T., Grau, E. G. \& Iwama G.K. (1997). Physiological and respiratory responses of the Mozambique tilapia (Oreochromis mossambicus) to salinity acclimation. Comparative Biochemistry and Physiology Part A, 117, 391-398.

47. Mozanzadeh, M.T., Safari, O., Oosooli, R., Mehrjooyan, S., Najafabadi, M.Z., Hoseini, S.J., Saghavi, H., Monem, J., 2021. The effect of salinity on growth performance, digestive and antioxidant enzymes, humoral immunity and stress indices in two euryhaline fish species: Yellowfin seabream (Acanthopagrus latus) and Asian seabass (Lates calcarifer). Aquaculture 534, 736329.

48. Paria, A., Dong, J., Babu, P.P., Makesh, M., Chaudhari, A., Thirunavukkarasu, A.R., Purushothaman, C.S. \& Rajendran, K.V. (2016). Evaluation of candidate reference genes for quantitative expression studies in Asian seabass (Lates calcarifer) during ontogenesis and in tissues of healthy and infected fishes. Indian Journal of Experimental Biology, 54, 597-605.

49. Partridge, G. J., \& Lymbery, A. J. (2008). The effect of salinity on the requirement for potassium by barramundi (Lates calcarifer) in saline groundwater. Aquaculture,278, 164-170.

50. Sakamoto, T., \& Hirano, T. (1993). Expression of insulin-like growth factor-I gene in osmoregulatory organs during seawater adaptation of the salmonid fish: Possible mode of osmoregulatory action of growth hormone. Proceedings of the National Academy of Sciences, 90, 1912-1916.

51. Sakamoto, T., \& McCormick, S. D. (2006). Prolactin and growth hormone in fish osmoregulation. General and Comparative Endocrinology, 147, 24-30.

52. Saoud, I.P., Kreydiyyeh, S., Chalfoun, A., \& Fakih, M. (2007). Influence of salinity on survival, growth, plasma osmolality and gill $\mathrm{Na}^{+}-\mathrm{K}^{+}-$ATPase activity in the rabbitfish Siganus rivulatus. Journal of Experimental Marine Biology and Ecology, 348, 183-190.

53. Seale, A. P., Riley, L.G., Leedom, T. A., Kajimura, S., Dores, R. M., Hirano, T., \& Grau, E. G. (2002). Effects of environmental osmolality on release of prolactin, growth hormone and ACTH from the tilapia pituitary. General and Comparative Endocrinology,128, 91-101.

54. Shrimpton, J. M., Devlin, R. H., McLean, E., Byatt, J. C., Donaldson, E. M., \& Randall, D. J. (1995). Increases in gill cytosolic corticosteroid receptor abundance and saltwater tolerance in juvenile coho salmon (Oncorhynchus kisutch) treated with growth hormone and placental lactogen. General and Comparative Endocrinology, 98, 1-15.

55. Schmitz, M., Baekelandt, S., Bequet, S., \& Kestemont, P. (2017). Chronic hyperosmotic stress inhibits renal Toll-Like Receptors expression in striped catfish (Pangasianodon hypophthalmus, Sauvage) exposed or not to bacterial infection. Developmental \& Comparative Immunology, 73, 139-143.

56. Smith, T. R., Tremblay, G. C., Bradley, T. M. (1999). Hsp70 and a 54 kDa protein (Osp54) are induced in salmon (Salmo salar) in response to hyperosmotic stress. Journal of Experimental Zoology, 284, 
286-298.

57. Sterzelecki, F.C., Rodrigues, E., Fanta, E., \& Ribeiro, C. A. O. (2013). The effect of salinity on osmoregulation and development of the juvenile fat snook, Centropomus parallelus (POEY). Brazilian Journal of Biology, 73, 609-615.

58. Stewart, H. A., Noakes, D. L. G., Cogliati, K. M., Peterson, J. T., Iversen, M. H., \& Schreck, C. B. (2016). Salinity effects on plasma ion levels, cortisol, and osmolality in Chinook salmon following lethal sampling. Comparative Biochemistry and Physiology Part A. 192, 38-43.

59. Uribe, C., Folch, H., Enriquez, R., \& Moran, G. (2011). Innate and adaptive immunity in teleost fish: a review. Veterinarni Medicina, 56, 486-503.

60. Vargas-Chacoff, L., Arjona, F.J, Polakof, S., Martın del Rio, M.P., Soengas, J.L., \& Mancera, J.M. (2009). Interactive effects of environmental salinity and temperature on metabolic responses of gilthead sea bream Sparus aurata. Comparative Biochemistry and Physiology Part A, 154, 417-424.

61. Vargas-Chacoff, L., Calvo, A., Ruiz-Jarabo, I., Villarroel, F., Munoz, J.L., Tinoco, A.B., Cardenas, S., \& Mancera, J.M. (2011). Growth performance, osmoregulatory and metabolic modifications in red porgy fry, Pagrus pagrus, under different environmental salinities and stocking densities. Aquaculture Research, 42, 1269-1278.

62. Varsamos, S., Diaz, J.P., Charmantier, G., Flik, G., Blasco, C., Connes, R. (2002) Branchial chloride cells in sea bass (Dicentrarchus labrax) adapted to fresh water, seawater and doubly concentrated seawater. Journal of Experimental Zoology, 293, 12-26.

63. Wagner, T., \& Congleton, J.L. (2004). Blood chemistry correlates of nutritional condition, tissue damage and stress in migrating juvenile Chinook salmon (Oncorhynchus tshawitscha). Canadian Journal of Fisheries and Aquatic Sciences, 61, 1066-1074.

64. Wendelaar-Bonga, S. E. (2011). Hormonal response to stress. In: Farrel, A. P. (ed) Encyclopedia of fish: fish physiology from genome to environment, vol 2. Academic Press, pp. 1515-1523.

65. Yano, T. (1996). The nonspecific immune system: humoral defense. In: Iwama, G., \& Nakanishi, T. (Eds.), The Fish Immune System: Organism, Pathogen, and Environment. Academic Press, San Diego, pp. 105-157.

66. Yada, T., Uchida, K., Kajimura, S., Azuma, T., Hirano, T., \& Grau, E. (2002). Immunomodulatory effects of prolactin and growth hormone in the tilapia, Oreochromis mossambicus. Journal of Endocrinology, 173, 483-492.

67. Yada, T., Uchida, K., Kajimura, S., Azuma, T., Hirano, T., \& Grau, E. (2002). Immunomodulatory effects of prolactin and growth hormone in the tilapia, Oreochromis mossambicus. Journal of Endocrinology, 173, 483-492.

68. Zeynali, M., Nafisi Bahabadi, M., Morshedi, V., Qasemi, A., \& Torfi Mozanzadeh, M. (2020).

Replacement of dietary fishmeal with Sargassum ilicifolium meal on growth, innate immunity and immune gene mRNA transcript abundance in Lates calcarifer juveniles. Aquaculture Nutrition, 26(5), 1657-1668. 


\section{Figures}

a

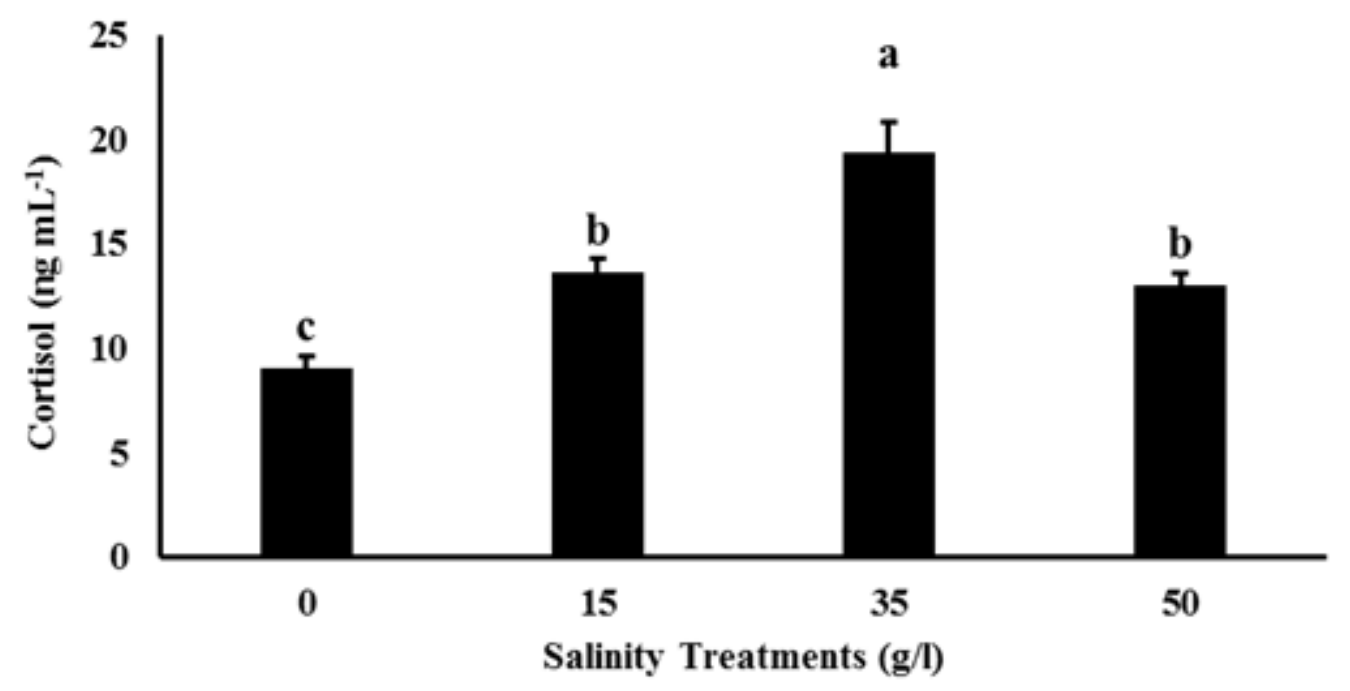

b

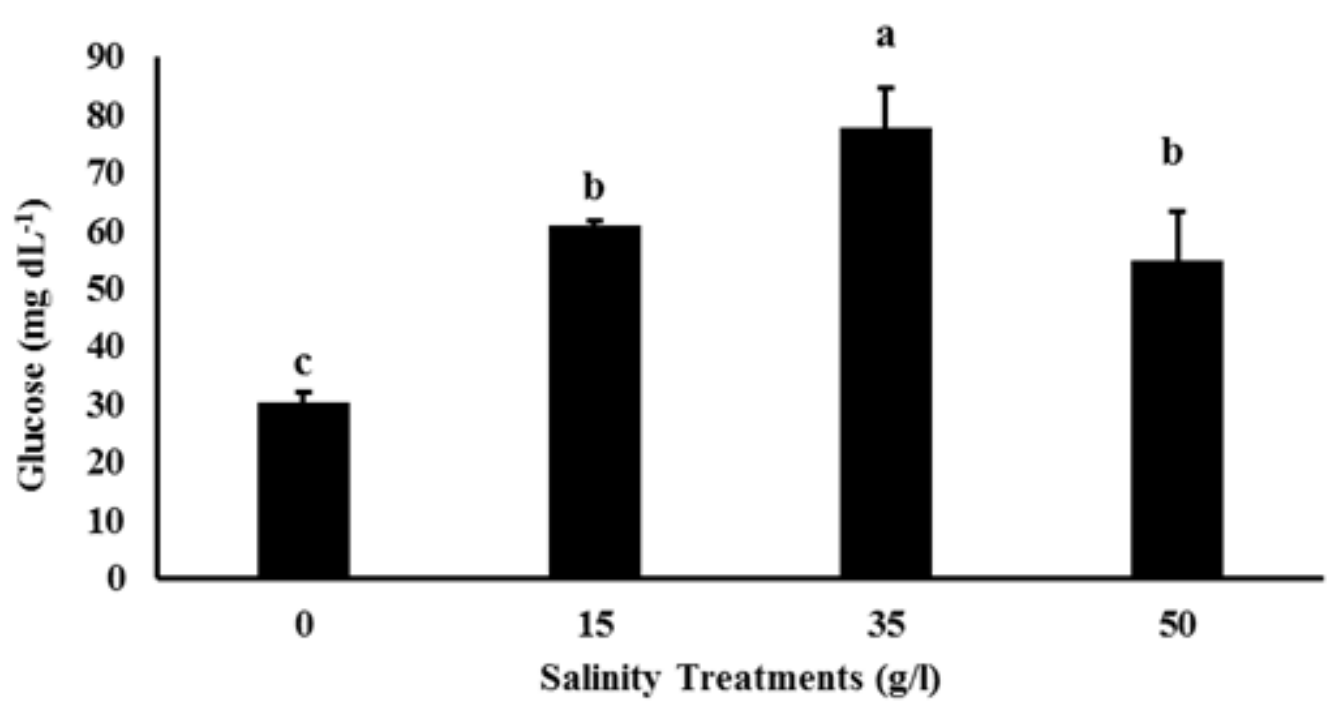

Figure 1

The survival rate in all groups was $100 \%$. The histological study of the gill demonstrated that fish reared at 15 and $35 \%$ o had more $C C$ counts in the interlamellar region $(P<0.05$, Table 2, Fig. 1, 2). The number of CC in the interlamellar region increased with increasing WS up to $35 \%$, but they decreased in fish reared at $50 \%$. The diameter of $\mathrm{CC}$ in the interlamellar region was not affected by WS. The nucleus diameter of CC in the interlamellar region in fish reared at 15\% was lower than the other groups $(P<$ 0.05). 


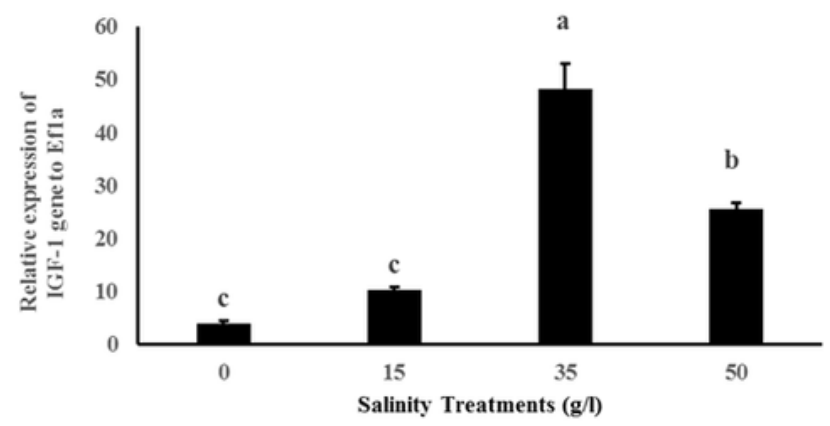

b
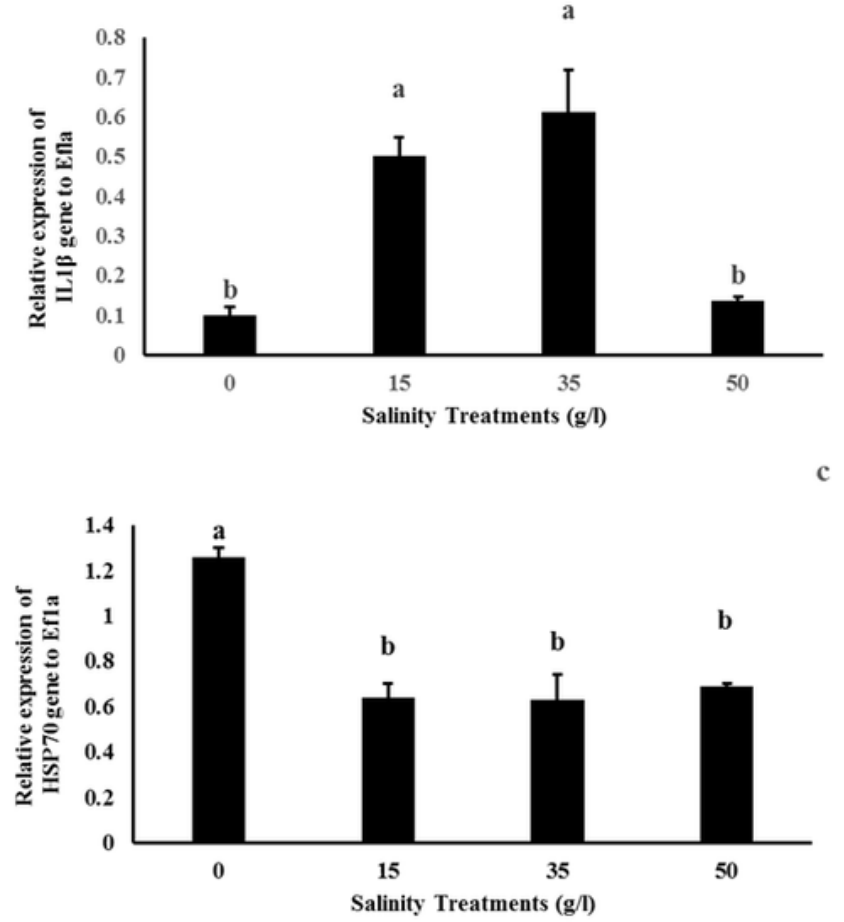

d

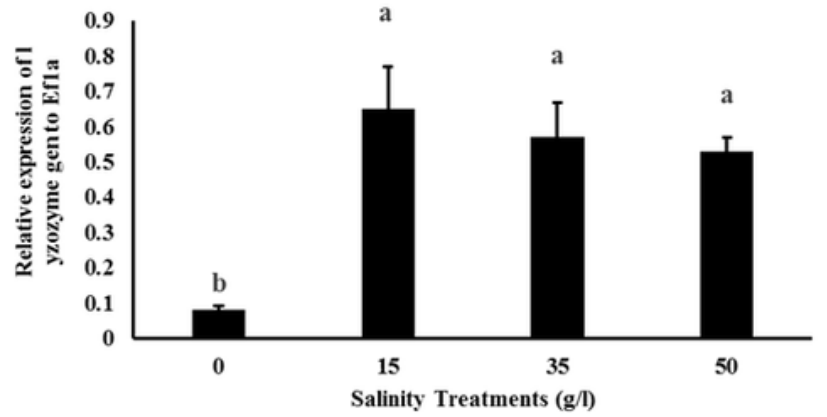

Figure 2

The survival rate in all groups was $100 \%$. The histological study of the gill demonstrated that fish reared at 15 and $35 \%$ o had more $C C$ counts in the interlamellar region $(P<0.05$, Table 2 , Fig. 1,2$)$. The number of CC in the interlamellar region increased with increasing WS up to $35 \%$, but they decreased in fish reared at $50 \%$. The diameter of CC in the interlamellar region was not affected by WS. The nucleus 
diameter of CC in the interlamellar region in fish reared at $15 \%$ was lower than the other groups $(\mathrm{P}<$ 0.05).
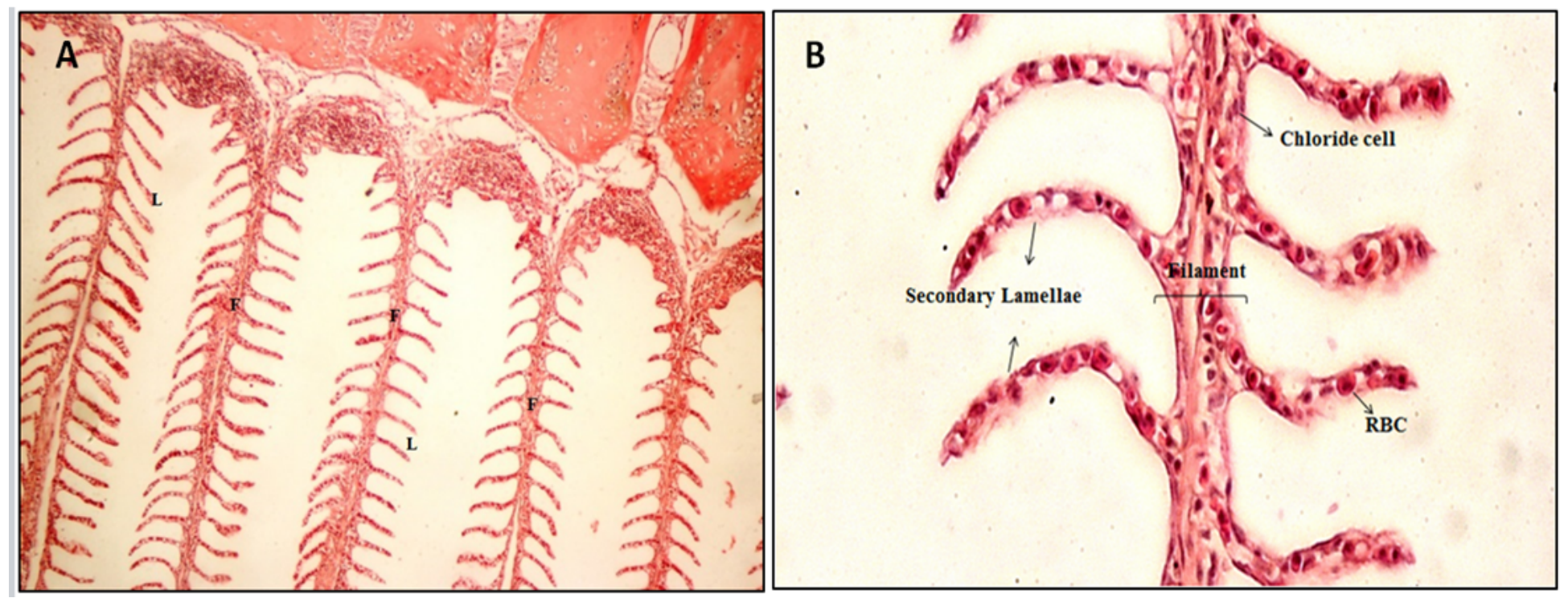

Figure 3

Serum cortisol (Fig. 3a) and glucose (Fig. 3b) levels gradually increased with elevation of WS up to 35\%o, then their contents remarkably decreased in serum of fish reared at $50 \%$.

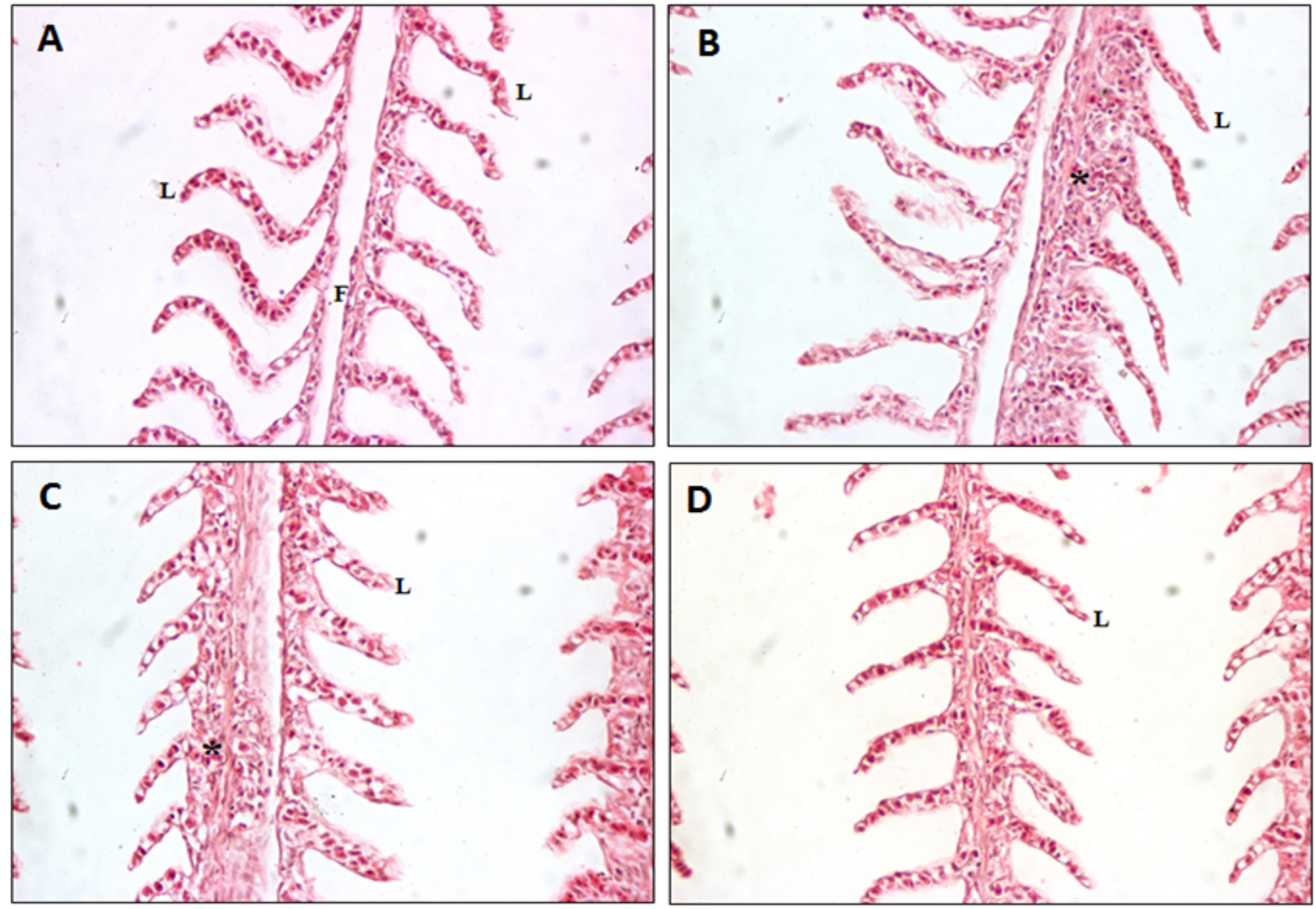




\section{Figure 4}

The relative expression of IGF-1 in the liver of fish reared at 35\%o was significantly higher than the other groups, but fish reared at fresh water and 15\%o showed the lowest liver IGF-1 gene expression (Fig. 4a). The relative expression of IL-1 $\beta$ in the liver of fish reared at 15 and $35 \%$ o was higher than at fresh water and $50 \%$ o (Fig. 4b). The relative expression of HSP70 gene in fish reared at fresh water was pronouncedly higher than other treatments (Fig. 4c); however, the relative expression of lysozyme gene in the liver of fish reared at fresh water was remarkably lower than those reared at salt waters (Fig. 4d). 